\title{
Productivity and Quality of Sugar Beet in Relation to Humic Acid and Boron Fertilization Under Nubaria Conditions
}

\author{
Ibrahim.F. Rehab ${ }^{1}$, Samia S. El Maghraby ${ }^{2}$, E. E. Kandil ${ }^{1}$ and Nahed Y. Ibrahim ${ }^{3}$
}

\begin{abstract}
Two field Experiments were conducted at $\mathrm{km} 48$ Nubaria region, Alex. Cairo Desert Road, El- Behiera Government, Egypt, during 2016/2017 and 2017/ 2018 seasons, to study the effect of three humic acid levels and four boron fertilization rates on yield and quality of sugar beet (Beta vulgaris $\mathbf{L}$.) cultivar monogerm (cv. Francisco). Treatments were arranged in a split- plot design in three replicates. The three humic acid levels $(0=$ water, 3 and 6

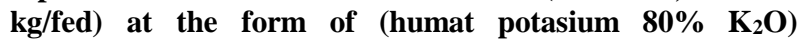
randomly assigned to the main plot. While, the four boron rates $(0,400,800$, and $1200 \mathrm{~g} / \mathrm{fed})$ were distributed at random within the sub plot at the form of Nutribor $(8 \%$ Boric acid). Seeds were hand sown on $3^{\text {rd }}$ and $5^{\text {th }}$ October 2016/2017 and 2017/2018 seasons, respectively, in each (sub - plot), at the rate of 1 seed ball per hill on one side of the ridge at $20 \mathrm{~cm}$ apart. Root yield (ton/fed), top yield(ton/fed), biological yield(ton/fed), sugar yield (ton/fed), TSS \%, sucrose $\%$, purity $\%$, extraction \%, potassium $\%, \alpha$-amino nitrogen $\%$, sodium $\%$, and white sugar $\%$, were determined in both seasons. The obtained results revealed that; 1 ). increasing humic acid rates from zero up to $6 \mathrm{~kg}$ /fed increased significantly root, biological, sugar yields ton/fed, TSS\%, potassium percentage and white sugar percentage during 2016/2017 and 2017/2018 seasons. Where, the highest mean values were obtained by adding the higher level of humic acid $(6 \mathrm{~kg} / \mathrm{fed})$. On the contrary, the lowest values were given by growing sugar beet plant under control treatment (zero $\mathrm{kg} / \mathrm{fed}$ humic acid). On the other hand, increasing humic acid rates from zero up to $6 \mathrm{~kg} / \mathrm{fed}$ decreased significantly extraction $\%$, $\alpha$-amino nitrogen $\%$, sodium $\%$, however, the lowest ones recorded with adding $6 \mathrm{~kg} / \mathrm{fed}$ humic acid. Nevertheless, under this study, the highest mean values of these traits were obtained with control (zero $\mathrm{kg} /$ fed humic acid) in both seasons, 2). increasing boron fertilization rates from zero to $400 \mathrm{~g} / \mathrm{fed}, 800 \mathrm{~g} / \mathrm{fed}$ and $1200 \mathrm{~g} / \mathrm{fed}$ increased significantly the mean values of root yield, sugar yield, the total soluble solids (\%), sucrose (\%), purity (\%), extraction $(\%)$ and white sugar $(\%)$. In addition, the highest mean values were recorded with application of $1200 \mathrm{~g} / \mathrm{fed}$, while the lowest mean values were obtained by growing sugar beet plant under the control treatment (zero boron= water) during the two seasons. On the contrast, increasing boron fertilization from zero up to $1200 \mathrm{~g} /$ fed decreased significantly potassium $\%, \alpha$ - amino nitrogen $(\%)$, and sodium (\%) in sugar beet root, meanwhile the lowest mean
\end{abstract}

values were recorded when applying the rate of $1200 \mathrm{~g} / \mathrm{fed}$ of boron fertilization. Whereas, the highest mean values were given under control treatment (zero g/fed) in the two seasons, 3). and the interaction between humic acid and boron fertilization affected significantly top yield ton/fed, biological yield ton/fed, the total soluble solids $\%$, sucrose $\%$, purity $\%, \alpha$ - amino nitrogen $\%$ and sodium $\%$ during both seasons and sugar yield ton/fed during the first season 2016/2017. This showed that humic acid and boron fertilization act dependently on top yield, biological yield and sugar yield of sugar beet plant under this study.

Keywords: Sugar beet, humic acid, boron, yield and quality.

\section{INTRODUCTION}

Sugar beet (Beta vulgaris, L.) considered the second important sugar crop after sugarcane. It is a vital crop to man as a source of high energy and as an important source of feed to livestock. The importance of this crop comes from its growing in the newly reclaimed land and giving a high sugar recovery, as well as its lower water requirement, compared to sugarcane. Moreover, sugar beet is specialized as a short duration crop, where its growth period is about half that of sugarcane. Also, sugar beet being often, the most important cash crop in the rotation, it leaves the soil in good conditions for the following summer cereal crop. So that, it became the first source for the production of sugar in Egypt, as repeated. The production of sugar from sugar beet reached $56.61 \%$ (1.27 Million tons) of sugar production in Egypt, while the sugar cane production was $43.39 \%$ (0.931 Million tons) according to Sugar Crops Council (2017).

Nowadays Egypt faces many problems that affect the productivity of crops in general and sugar crops in particular, including sugar beet, which evolves, significantly, at the moment. Therefore, that humic acid (HA) is a main component of humic substances, which are the major soil organic constituents (humus). It is produced by biodegradation of organic matter. Humic acid is not a single acid; rather, it is a complex mixture of virous acids containing carboxyl and phenolate groups. Humic acids contain form complexes and ions that are commonly found in the environment creating

\footnotetext{
DOI: 10.21608/ASEJAIQJSAE.2019.29029

1. Plant Production Department, Faculty of Agriculture (Saba Basha), Alexandria University, Egypt.

${ }^{2}$ Sugar Crops Research Institute, Agriculture Research Centre, Giza, Egypt.

${ }^{3}$ Sugar Cane Research Station, El- Sabaheia, Alexandria, Agriculture Research Centre.

Received February 16, 2019, Accepted March 19, 2019
} 
humic colloids. Fulvic acids are humic acids of lower molecular weight and higher oxygen content than other humic acids however, they are commonly used as a soil supplement in agriculture. Whereas, Gomaa et al. (2014) reported that application humic acid at $6 \mathrm{~kg} / \mathrm{fed}$ increased significantly grain yield of maize. Also, Rassam at el. (2015) studied the effect of using the humic acid in calcareous soil at concentrations, no application (zero) humic acid, $2.5 \mathrm{l} /$ ha and $5 \mathrm{l} / \mathrm{ha}$., the application of humic acid caused a significant increase of sucrose \%, root yield and refined sugar yield and a reduction in molasses forming substances content, compared to the control. However, EL-Hassanin at el. (2016) reported that foliar application of humic acid statistically improved sucrose, extractable sugar, purity, sugar lost to molasses, extractability percentages and yield of sugar beet.

Boron is an essential micro -nutrient for plants. Foliar application of boron is involved in several physiological and biochemical processes during plant growth. In general, sugar beet in special, boron it plays a major role in sugar transport as well as in formation and maintenance of cell wall and cell membrane integrity and consequently, high root yield, and sugar content (Kabu and Akosman, 2013). Foliar application of boron improved root weight/plant, top, root and sugar yields/fed and root quality percentage sugar, T.S.S\%, purity $\%$ and extractable white sugar. In other wise, application of boron reduced $\mathrm{N}, \mathrm{Na}, \mathrm{K}$ contents, $\alpha$ amino-N and loss sugar percentage (Armin and Asharipour, 2012; El- Sherief et al., 2016). An insufficient boron due to reduction in yield and sugar \% in sugar beet production. This is because boron is involved in the process of transportation and disposal of sugar in the roots. The greatest need for boron is in the stage of intense leave growth, from closing the ranks even reaching the maximum leaf surface. Compared to the control variant, both boron fertilization (1 or $2 \mathrm{~kg}$ $\mathrm{B} / \mathrm{ha}$ ), variants achieved significant higher yield, sugar $\%$ and pure sugar yield (Kristek et al., 2018).

Therefore, the objectives of the present work were to study the effect of humic acid and boron fertilization on yield and quality of sugar beet under Nubaria Region, EL- Behiera Governorate.

\section{MATERIALS AND METHODS}

Two field Experiments were conducted at $\mathrm{Km} 48$ Nubaria region, Alexandria Cairo Desert Road, ElBehiera Government, Egypt during the two successive seasons of 2016/2017 and 2017/2018, to study effect of humic acid and boron fertilization on yield and quality of sugar beet (Beta vulgaris L.) cultivar monogerm (cv. Francisco), which obtained from Sugar Crop Research, Institute Agricultural Research Center, Giza.
The preceding summer crop was maize (Zea mays L.) in both seasons. Before soil preparation, soil samples were taken at a depth of $0: 30 \mathrm{~cm}$ from different experimental sites, to determine physical and chemical properties of soil according to Piper (1950) as shown in Table (1).

Table 1. Some physical and chemical properties of the experimental soil in 2016/2017 and 2017/ 2018 seasons

\begin{tabular}{|c|c|c|}
\hline \multirow[b]{2}{*}{ Soil properties } & \multicolumn{2}{|c|}{ Season } \\
\hline & $2016 / 2017$ & $\begin{array}{l}2017 / \\
2018\end{array}$ \\
\hline \multicolumn{3}{|l|}{ A- Mechanical analysis } \\
\hline Sand \% & 66.32 & 65.41 \\
\hline Clay $\%$ & 11.43 & 11.95 \\
\hline Silt $\%$ & 22.25 & 22.64 \\
\hline \multicolumn{3}{|l|}{ B-Soil texture } \\
\hline $\mathrm{pH}(1: 1)$ & 8.25 & 8.10 \\
\hline E.C. $(\mathrm{ds} / \mathrm{m})$ & 1.78 & 1.81 \\
\hline \multicolumn{3}{|l|}{1 - Soluble cations $(1: 2)$} \\
\hline \multicolumn{3}{|l|}{$\overline{(\mathrm{Cmo} 1 / \mathrm{kg} \text { soil })}$} \\
\hline $\mathrm{K}^{+}$ & 1.30 & 1.40 \\
\hline $\mathrm{Ca}^{++}$ & 3.50 & 3.30 \\
\hline $\mathrm{Mg}^{++}$ & 2.50 & 2.60 \\
\hline $\mathrm{Na}^{++}$ & 4.45 & 4.65 \\
\hline \multicolumn{3}{|l|}{ 2- Soluble anions $(1: 2)$} \\
\hline (Cmo1/kg soil) & 3.73 & \\
\hline $\mathrm{CO}_{3}^{-}+\mathrm{HCO}_{3}^{-}$ & $\begin{array}{l}5.13 \\
7.08\end{array}$ & 7.30 \\
\hline $\begin{array}{l}\mathrm{CL}^{-} \\
\mathrm{SO}_{4}^{-}\end{array}$ & 0.96 & 0.83 \\
\hline Calcium carbonate & 15.02 & 18.03 \\
\hline Total nitrogen $(\mathrm{mg} / \mathrm{kg})$ & 20.00 & 19.10 \\
\hline $\begin{array}{l}\text { Available Phosphorus } \\
(\mathrm{mg} / \mathrm{kg})\end{array}$ & 3.14 & 3.19 \\
\hline Organic matter $\%$ & 0.83 & 0.93 \\
\hline Available B(mg/kg) & 0.03 & 0.06 \\
\hline
\end{tabular}

All treatments were arranged in a split- plot design in three replicates. The treatments of the experiment were as follows:

I- Humic acid levels (Main plots):

1- $\left(\mathrm{H}_{1}\right)$ without humic acid = spraying water as control.

2- $\left(\mathrm{H}_{2}\right) 3 \mathrm{Kg}$ humic acid/fed.

3- $\left(\mathrm{H}_{3}\right) 6 \mathrm{Kg}$ humic acid/ fed.

II -Boron fertilizer levels (Sub plots):

1- (B1) without boron= spraying water as control.

2- (B2) $400 \mathrm{~g}$ boron / fed.

3- (B3) $800 \mathrm{~g}$ boron / fed.

4- (B4)1200 g boron /fed.

The experimental field was prepared through ploughing, and calcium super phosphate $\left(15.5 \% \mathrm{P}_{2} \mathrm{O}_{5}\right)$ 
was applied during tillage operation at the rate of 100 $\mathrm{Kg} /$ fed. Potassium sulfate $\left(48 \% \mathrm{~K}_{2} \mathrm{O}\right)$ was applied at the rate of $50 \mathrm{Kg} /$ fed $\left(24 \mathrm{Kg} \mathrm{K}_{2} \mathrm{O} / \mathrm{fed}\right)$. Nitrogen fertilizer was adding in from of urea $(46 \% \mathrm{~N})$ the rate of $100 \mathrm{~kg} \mathrm{~N} / \mathrm{fed}$, in two equal doses on half after thinning (before the first irrigation) and the other half before the second irrigation. Monogerm seeds (Francisco) cultivars was hand sown on $3^{\text {rd }}$ and $5^{\text {th }}$ October in 2016/2017 and 2017/2018 seasons, respectively, at the rate of 1 seed ball per hill on one side of the ridge in hill $20 \mathrm{~cm}$ apart. The experimental basic unit area was $10.5 \mathrm{~m}^{2}(1 / 400$ fed.) and included 5 ridges each of which $60 \mathrm{~cm}$ width and 3.5 meters' length.

The three humic acid levels $(0,3$ and $6 \mathrm{~kg} / \mathrm{fed})$ at the form of (humat potasium $80 \% \quad \mathrm{~K}_{2} \mathrm{O}$ ) randomly assigned to the main plot treatment at one dose after thinning (before the second irrigation) after fifty days of planting. The four boron rates $(0,400,800$ and $1200 \mathrm{~g} /$ fed) were distributed at random as the subplot at the form of Nutribor ( $8 \%$ Boric acid) sprayed twice after 120 and 150 days from planting. All other cultural practices were carried out as recommended by Sugar Crops Research Institute, Agricultural Research Center, Giza, Ministry of Agriculture and Land Reclamation.

At harvest time, 180 days from planting in both seasons. Plant of all ridges of each sub plot, were harvested, cleaned, topped and weighed and the following characters were determined in both seasons; Root yield (ton/fed), top yield (ton/fed), biological yield (ton/fed), sugar yield (ton/fed), TSS\%, sucrose $\%$, purity $(\%)$, extraction $(\%)$, potassium $(\%), \alpha$-amino nitrogen $(\%)$, sodium $(\%)$, and white sugar $(\%)$.

The statistical analysis was carried out according to Steel and Torrie (1981). Treatment means were compared by L.S.D at 0.05 level of probability. The analysis of variance (ANOVA) was computed using CoStat V 6.4 (2005) program.

\section{RESULTS AND DISCUSSION}

Result in Table (2) showed the effect of humic acid, boron fertilization and their interaction on some yield attributes of sugar beet during 2016/2017 and 2017/2018 seasons.

Increasing humic acid (HA) rates from zero up to 6 $\mathrm{kg} / \mathrm{fed}$ increased significantly root yield (ton /fed), biological yield (ton/fed) and sugar yield (ton/fed) during 2016/2017 and 2017/2018 seasons. The highest mean values were obtained by adding the highest application rate of humic acid (6 kg /fed). On the contrary the lowest mean values were obtained by growing sugar beet plant under control treatment (zero $\mathrm{kg} / \mathrm{fed}$ ) humic acid. Meanwhile there was a significant increase in top yield (ton / fed) of sugar beet plants by increasing humic acid rates from zero up to $3 \mathrm{~kg} / \mathrm{fed}$, further increase up to $6 \mathrm{~kg} / \mathrm{fed}$ had no significant effect on the mean values of top yield during both seasons as shown in Table (2). These results are in harmony with those obtained by Shoae et al (2013), Motaghi and Nejad (2014), Shaban et al. (2014), Rassam at el. (2015) and EL-Hassanin at el. (2016) who revealed that increasing humic acid make up an increase in yield and its components of sugar beet.

Results in the same table showed that increasing boron fertilization rates from zero to $400 \mathrm{~g} / \mathrm{fed}, 800$ $\mathrm{g} / \mathrm{fed}$ and $1200 \mathrm{~g} / \mathrm{fed}$ increased significantly the mean values of root yield ton /fed and sugar yield ton/fed during 2016/2017 and 2017/2018 seasons. In addition the highest mean values of root yield (25.48 and 23.34 ton / fed ) as well as the highest mean values of sugar yield (5.16 ton / fed and 4.77 ton / fed), were recorded when applying the $1200 \mathrm{~g} /$ fed concentration of boron fertilization, whereas, the lowest mean values of root yield (21.21 and 19.92 ton /fed), as well the lowest mean values of sugar yield (3.98 ton /fed and 3.75 ton /fed) were obtained by growing sugar beet plant under the control treatment ( zero boron fertilization= water) during $2016 / 2017$ and 2017/2018 seasons, respectively. The results are in harmony with these obtained by Saif (1991), Armin and Asharipour (2012), El- Sherief et al. (2016) and Kristek et al. (2018) who reported that foliar application of boron increased yield and its components of sugar beet.

Result in Table (2) determined that increasing boron fertilization from zero up to $1200 \mathrm{~g} / \mathrm{fed}$ had no significant effect on top yield of sugar beet plant during the first season (2016/2017). On the contrary during the second season, application of boron fertilization rates affected significantly the top yield ton / fed, where the highest mean value (9.19 ton / fed) produced at control treatment (zero g/fed boron) and the lowest value (6.89 ton / fed) realized under boron concentration of $1200 \mathrm{~g} /$ fed.

Results in the same table also stated that increasing boron fertilization from zero up to $1200 \mathrm{~g} / \mathrm{fed}$ insignificantly affected the biological yield during the second season (2017/2018) Nevertheless, in the first season it significantly affected the biological yield, where the highest mean value 35.23 ton / fed at (boron $1200 \mathrm{~g} / \mathrm{fed}$ ) and the lowest mean value 31.60 ton / fed resulted under control treatment. The results are in harmony with these obtained by EL- Geddawy et al. (2007), Osman (2008), Mekdad (2015) and AbdelMotagally (2015) who reported that foliar application of boron increased yield and its components of sugar beet.

The interaction between humic acid and boron fertilization affected significantly top yield, biological 
Table 2. Some yield attributes of sugar beet as affected by humic acid, boron fertilization rates and their interaction during $2016 / 2017$ and $2017 / 2018$ seasons

\begin{tabular}{|c|c|c|c|c|c|c|c|c|}
\hline \multirow{2}{*}{ Treatments } & \multicolumn{2}{|c|}{ Root yield (ton/fed) } & \multicolumn{2}{|c|}{ Top yield (ton/fed) } & \multicolumn{2}{|c|}{ Biological yield (ton/fed) } & \multicolumn{2}{|c|}{ Sugar yield (ton/fed) } \\
\hline & $2016 / 17$ & $2017 / 18$ & $2016 / 17$ & $2017 / 18$ & $2016 / 17$ & $2017 / 18$ & $2016 / 17$ & $2017 / 18$ \\
\hline \multicolumn{9}{|l|}{ H) Humic acid (kg/fed) } \\
\hline $\mathrm{B}_{1}(0)$ water spraying & $20.62 c$ & $16.15 \mathrm{c}$ & $8.83 b$ & $5.99 b$ & $29.46 c$ & 22.14 & $3.92 \mathrm{c}$ & $3.04 \mathrm{c}$ \\
\hline $\mathrm{H}_{2}$ & $23.21 b$ & $22.02 b$ & $10.64 \mathrm{a}$ & $9.11 \mathrm{a}$ & $33.85 b$ & 31.13 & $4.53 b$ & $4.31 b$ \\
\hline $\mathrm{H}_{3} \quad(6)$ & $26.86 a$ & $26.45 a$ & $11.72 \mathrm{a}$ & $9.69 \mathrm{a}$ & $38.13 \mathrm{a}$ & 36.15 & $5.31 \mathrm{a}$ & $5.38 \mathrm{a}$ \\
\hline LSD at 0.05 & 2.30 & 2.56 & 0.77 & 0.70 & 2.97 & 2.28 & 0.50 & 0.48 \\
\hline \multicolumn{9}{|l|}{ B) Boron (g/fed) } \\
\hline $\mathrm{B}_{1}(0)$ water spraying & $21.21 \mathrm{c}$ & $19.92 \mathrm{c}$ & $10.38 \mathrm{a}$ & $9.19 \mathrm{a}$ & $31.60 \mathrm{~b}$ & 29.11 & $3.98 \mathrm{c}$ & $3.75 \mathrm{~d}$ \\
\hline $\mathrm{B}_{2}(400)$ & $23.16 b$ & $20.80 c$ & $10.69 a$ & $8.82 \mathrm{ab}$ & $33.85 \mathrm{a}$ & 29.62 & $4.53 b$ & $4.04 \mathrm{c}$ \\
\hline $\mathrm{B}_{3}(800)$ & $24.39 \mathrm{ab}$ & $22.11 b$ & $10.16 a$ & $8.16 b$ & $34.56 \mathrm{a}$ & 30.27 & $4.71 b$ & $4.41 b$ \\
\hline $\mathrm{B}_{4}(1200)$ & $25.48 \mathrm{a}$ & $23.34 \mathrm{a}$ & $9.75 \mathrm{a}$ & $6.89 c$ & $35.23 a$ & 30.23 & $5.16 \mathrm{a}$ & $4.77 \mathrm{a}$ \\
\hline LSD at 0.05 & 1.43 & 0.95 & NS & 0.67 & 2.09 & NS & 0.27 & 0.20 \\
\hline \multicolumn{9}{|l|}{ Interaction } \\
\hline $\mathrm{H} \times \mathrm{B}$ & NS & NS & 2.99 & 2.02 & 6.28 & 3.92 & 0.82 & NS \\
\hline
\end{tabular}

Means followed by the same letter in the same column are statistically equaled according to L.S.D 0.05 values.

NS: not significant difference at 0.05 level of probability. 


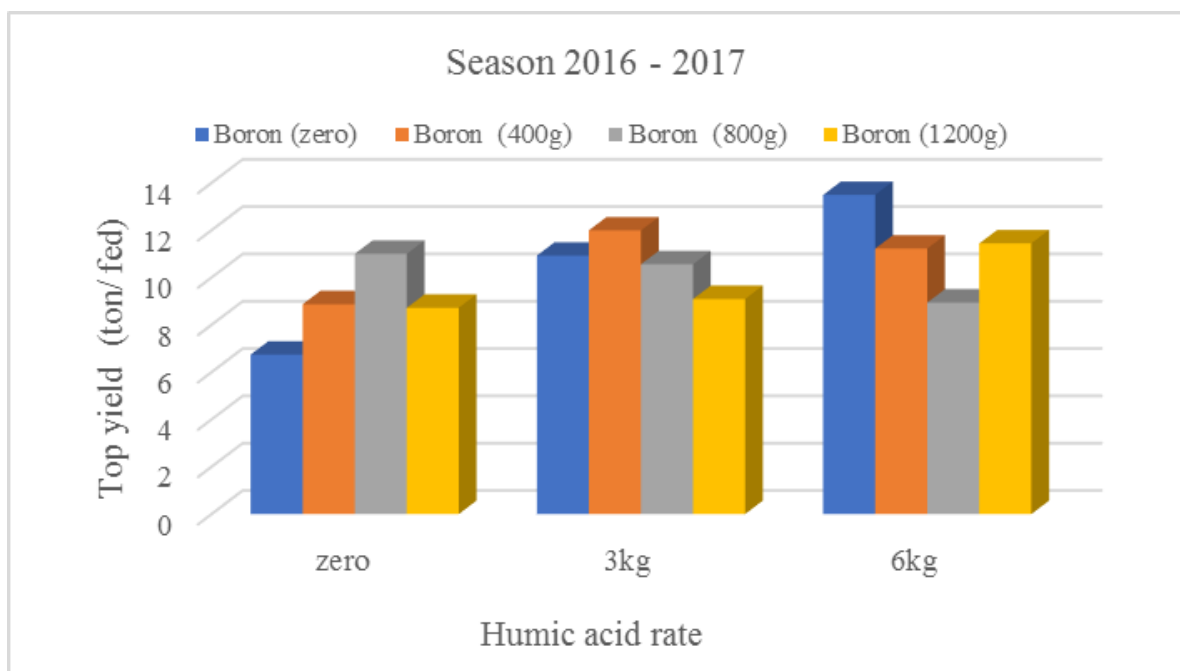

Fig 1.a. Top yield of sugar beet as affected by interaction between humic acid and boron fertilization during 2016/2017 season

Season 2016 - 2017

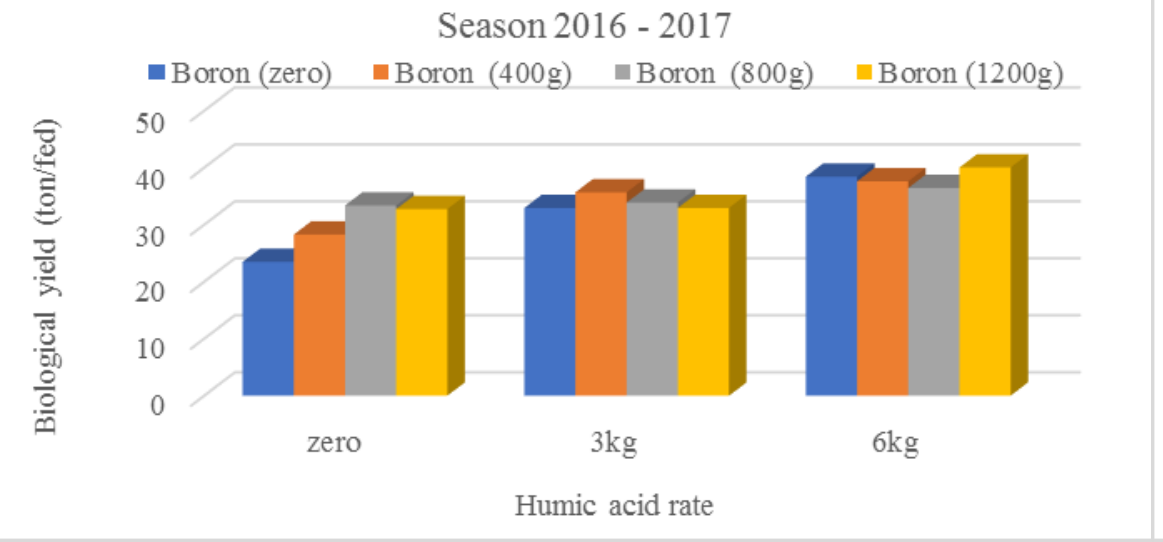

Fig 1.a. Biological yield of sugar beet as affected by interaction between humic acid and boron fertilization during 2016/2017 season

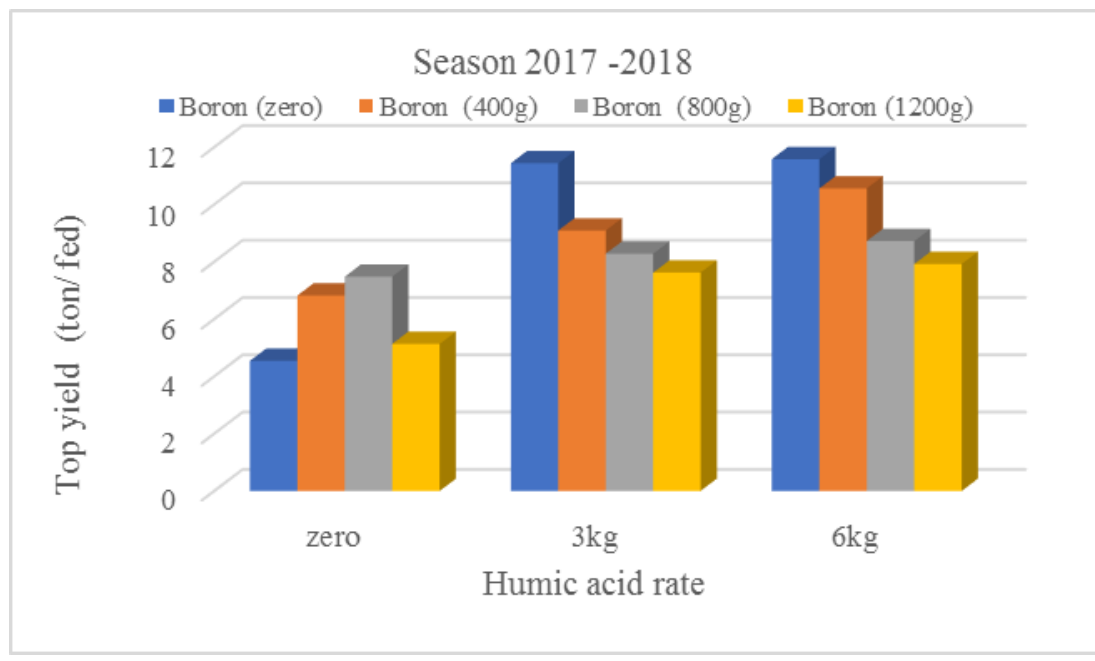

Fig 1.b. Top yield of sugar beet as affected by interaction between humic acid and boron fertilization during $2017 / 2018$ season Season 2017 - 2018

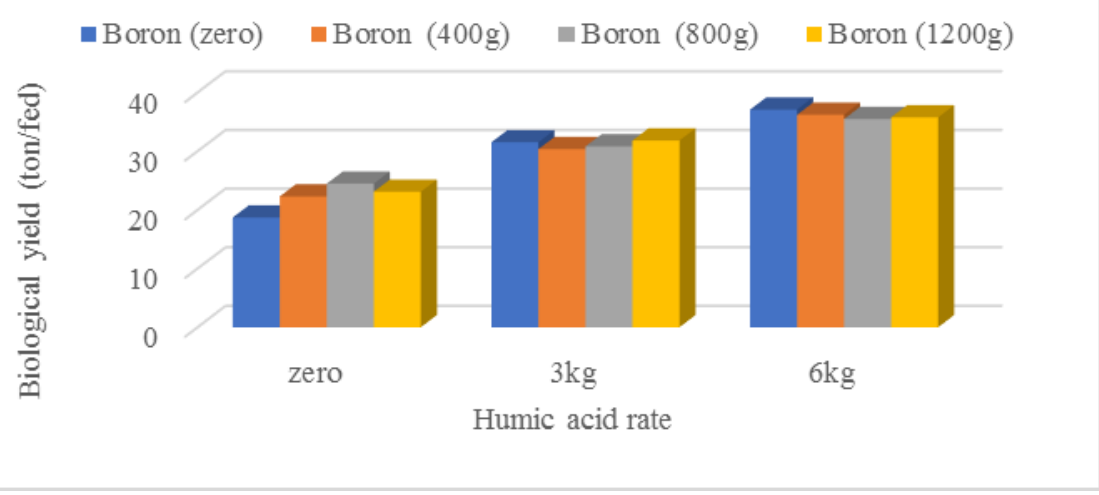

Fig 2.a. Biological yield of sugar beet as affected by interaction between humic acid and boron fertilization during 2017/2018 season 
yield during 2016/2017 and 2017/2018 seasons and sugar yield during the first season 2016/2017 as shown in Table (2). This showed that humic acid and boron fertilization act dependently on top yield, biological yield and sugar yield of sugar beet plant under this study. This showed that under this study humic acid and boron fertilization act independently on root yield. In this respect figures $1 \mathrm{a}, \mathrm{b}$ and $2 \mathrm{a}$ and $\mathrm{b}$ revealed that the highest top yield and biological yield/fed were recorded with foliar application of humic acid at the rate of 6 $\mathrm{kg} / \mathrm{fed}$ and boron at the rate of $1200 \mathrm{~g} / \mathrm{fed}$ in both seasons. While, the lowest ones recoded with no application of humic acid and boron (water spraying) in both seasons.

In addition, data in Table (2) showed that the interaction between humic acid and boron fertilization had no significant effect on root yield ton/fed during the two seasons 2016/2017 and 2017/2018.

Results in Table (3) showed the effect of humic acid, boron fertilization and their interaction on sugar beet TSS\%, sucrose $\%$, purity $\%$ and extraction $\%$ of sugar during 2016/2017 and 2017/ 2018 seasons.

Results in that table recorded that increasing humic acid from zero up to $6 \mathrm{~kg} / \mathrm{fed}$ increased significantly the total soluble solids percentage during 2016/2017 and 2017/2018 seasons and sucrose percentage during the second season 2017/2018, Where the highest mean values of TSS (23.61 and23.68\%) when adding $6 \mathrm{~kg} /$ fed. However, the lowest mean values of TSS $(21.80$ and $22.11 \%$ ) were obtained under the control treatment (zero humic acid) during the first and second seasons, respectively. While there, was no significant effect between the applications of. $3 \mathrm{~kg} / \mathrm{fed}$ and $6 \mathrm{~kg} / \mathrm{fed}$ on sucrose (\%) during 2016/2017 season, as well as between the applications of zero $\mathrm{kg} / \mathrm{fed}$ and $3 \mathrm{~kg} / \mathrm{fed}$ on TSS\% during 2017/2018 season. These results are in agreement with those obtained by Motaghi and Nejad (2014) and Shaban et al. (2014) who reported that quality traits of sugar beet were significantly increased by increasing the rate of humic acid.

The results listed in Table (3) showed that increasing humic acid rates from zero up to $3 \mathrm{~kg} / \mathrm{fed}$ increased significantly purity percentage during 2016/2017 and $2017 / 2018$ seasons. Where the highest mean values obtained under the application of $3 \mathrm{~kg} / \mathrm{fed}$ humic acid. While the lowest mean values were under control, treatment zero $\mathrm{kg} / \mathrm{fed}$ humic acid during the two seasons. This result may be due to the effect of humic acid on soduim, potassium and $\alpha$-amino nitrogen percentages in sugar beet root. The result is in confirmed with those reported by Motaghi and Nejad (2014) and Shaban et al. (2014).
Also, data presented in table (3) demonstrated that increasing humic acid rates decreased significantly extraction percentage during 2016/2017 and 2017/2018 seasons. Where the lowest mean values produced when adding $6 \mathrm{~kg} / \mathrm{fed}$ humic acid. Nevertheless, under this study, the highest mean values recorded under control treatment zero $\mathrm{kg} /$ fed humic acid during 2016/2017 and $2017 / 2018$ seasons. This result is to be expected due to the increase of potassium nitrate in the juice when the addition of the humic acid, which would block the crystallization of sugar and increase losses in molasses. The results are in the same line with those obtained by Motaghi and Nejad (2014) and Shaban et al. (2014).

Results reported in in same table pointed out determined that increasing boron fertilization from zero up to $1200 \mathrm{~g} / \mathrm{fed}$ increased, significantly, the total soluble solids \%, sucrose $\%$ and extraction \% during 2016/2017 and 2017/2018 seasons. Where the highest mean values of total soluble solids $\%$, sucrose $\%$ and extraction $\%$ were recorded when applying the concentration of 1200 $\mathrm{g} / \mathrm{fed}$, while the lowest mean values were obtained under the control treatment (zero g/fed boron) during $2016 / 2017$ and 2017/2018 seasons. The results are in harmony with that obtained by Nemeat-alla and ELGeddawy (2002), Aly (2005), Azzazy (2006), ELGeddawy et al (2007), and EL-Kamash (2007) who reported that foliar application of boron increased quality of sugar beet.

In addition, the study confirmed that boron fertilization increased the sugar yield as shown previously in Table (2) and decreased the proportion of some salts in the juice and increased the percentage of sugar to increase the proportion of (white sugar) percentage and thus the lack of sugar loss, which increases the percentage of extraction. These results are also consistent, with that in a study of Ferweez et al. (2011) who stated that using the spray of boric acid gave a significant effect on quality characteristics (pol\%, Na, $\mathrm{K}$, a- $\mathrm{N}$ contents and sugar recovery $\%$ ).

The interaction between humic acid and boron fertilization affected significantly the total soluble solids $\%$, sucrose $\%$ and purity $\%$ during 2016/2017 and 2017/2018 seasons and extraction (\%) during the second season only as shown in Table (3). This showed that humic acid and boron fertilization act dependently on total soluble solids $(\%)$, sucrose $(\%)$, purity $(\%)$ and extraction\% of sugar beet plant under this study. In this concern, figures $3 \mathrm{a}, \mathrm{b}$ and $4 \mathrm{a}$ and $\mathrm{b}$ revealed that the highest mean values of TSS and sucrose (\%) were given with foliar application of humic acid at the rate of 6 $\mathrm{kg} / \mathrm{fed}$ and boron at the rate of $1200 \mathrm{~g} / \mathrm{fed}$ during both seasons. While, the lowest ones recoded with no 
Table 3. TSS (\%), sucrose (\%), purity (\%) and extraction (\%) of sugar of sugar beet as affected by humic acid, boron fertilization and their interaction during 2016/2017 and 2017/ 2018 seasons

\begin{tabular}{|c|c|c|c|c|c|c|c|c|}
\hline \multirow[t]{2}{*}{ Treatments } & \multicolumn{2}{|c|}{ Total soluble solids (T.S.S \%) } & \multicolumn{2}{|c|}{ Sucrose $\%$} & \multicolumn{2}{|c|}{ Purity $\%$} & \multicolumn{2}{|c|}{ Extraction $\%$} \\
\hline & $2016 / 17$ & $2017 / 18$ & $2016 / 17$ & $2017 / 18$ & $2016 / 17$ & $2017 / 18$ & $2016 / 17$ & $2017 / 18$ \\
\hline \multicolumn{9}{|l|}{ H) Humic acid (kg/fed) } \\
\hline $\mathrm{H}_{1}(0)$ water spraying & $21.80 \mathrm{c}$ & $22.11 b$ & $19.05 b$ & $18.78 \mathrm{c}$ & $84.7 \mathrm{c}$ & $84.9 \mathrm{~b}$ & $87.24 \mathrm{a}$ & $86.76 a$ \\
\hline $\mathrm{H}_{2} \quad$ (3) & $22.51 b$ & $22.51 b$ & $19.50 \mathrm{a}$ & $19.52 b$ & $86.6 \mathrm{a}$ & $86.6 \mathrm{a}$ & $86.69 b$ & $86.62 \mathrm{ab}$ \\
\hline $\mathrm{H}_{3} \quad(6)$ & $23.61 \mathrm{a}$ & $23.68 \mathrm{a}$ & $19.77 \mathrm{a}$ & $20.35 a$ & $86.1 \mathrm{~b}$ & $86.2 \mathrm{a}$ & $86.99 \mathrm{ab}$ & $86.45 b$ \\
\hline LSD at 0.05 & 0.36 & 0.43 & 0.27 & 0.91 & 0.31 & 0.52 & 0.37 & 0.23 \\
\hline \multicolumn{9}{|l|}{ B) Boron (g/fed) } \\
\hline $\mathrm{B}_{1}(0)$ water spraying & $21.89 c$ & $21.93 \mathrm{~d}$ & $18.60 \mathrm{c}$ & $18.64 d$ & $84.9 c$ & $85.0 \mathrm{c}$ & $84.90 \mathrm{~d}$ & $84.71 \mathrm{~d}$ \\
\hline $\mathrm{B}_{2}(400)$ & $22.59 \mathrm{~b}$ & $22.35 c$ & $19.49 b$ & $19.32 \mathrm{c}$ & $86.3 \mathrm{a}$ & $86.4 a$ & $86.88 \mathrm{c}$ & $86.31 \mathrm{c}$ \\
\hline $\mathrm{B}_{3}(800)$ & $22.55 b$ & $23.02 b$ & $19.40 \mathrm{~b}$ & $19.83 b$ & $85.9 \mathrm{~b}$ & $86.1 b$ & $87.44 b$ & $86.94 b$ \\
\hline $\mathrm{B}_{4}(1200)$ & $23.53 \mathrm{a}$ & $23.77 \mathrm{a}$ & $20.27 \mathrm{a}$ & $20.41 \mathrm{a}$ & $86.1 \mathrm{ab}$ & $86.3 \mathrm{ab}$ & $88.68 \mathrm{a}$ & $88.47 \mathrm{a}$ \\
\hline LSD at 0.05 & 0.24 & 0.41 & 0.27 & 0.91 & 0.26 & 0.28 & 0.52 & 0.45 \\
\hline \multicolumn{9}{|l|}{ Interaction } \\
\hline $\mathrm{H} \times \mathrm{B}$ & 0.72 & 1.23 & 0.23 & 0.32 & 0.80 & 0.85 & NS & 1.34 \\
\hline
\end{tabular}

Means followed by the same letter in the same column are statistically equaled according to L.S. D 0.05 values

NS: not significant difference at 0.05 level of probability. 


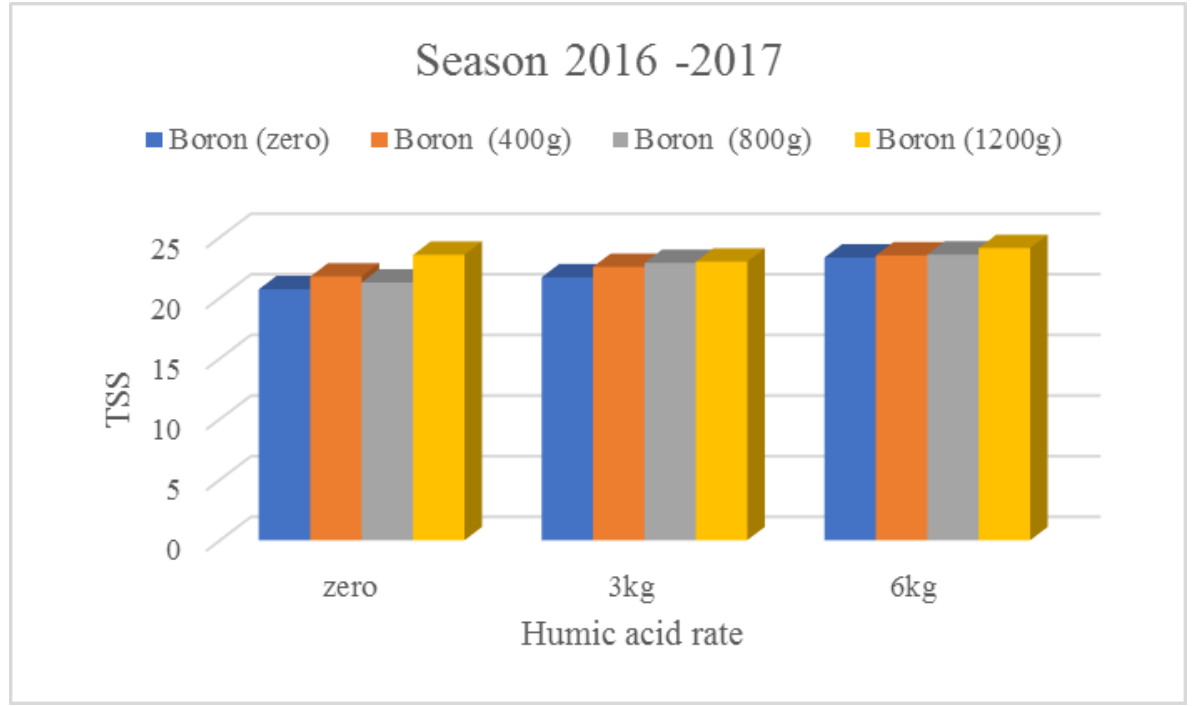

Fig 3.a. Total soluble solid (TSS) of sugar beet as affected by interaction between humic acid and boron fertilization during 2016/2017 season

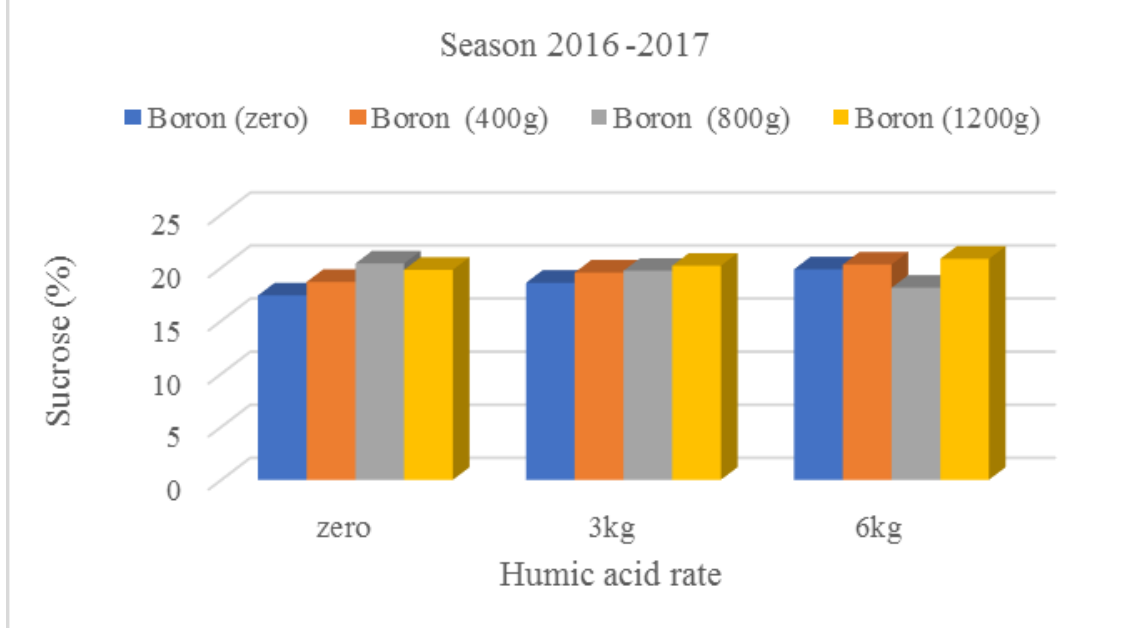

Fig 4.a. Sucrose (\%) of sugar beet as affected by interaction between humic acid and boron fertilization during 2016/2017 season

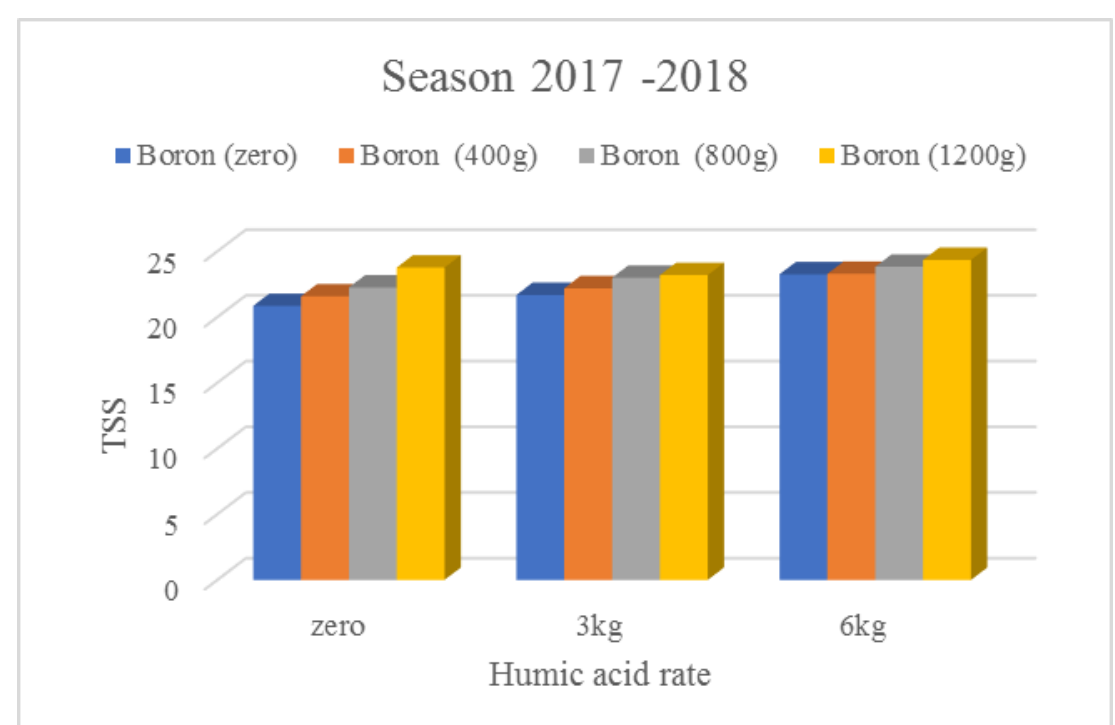

Fig 3.b. Total soluble solid (TSS) of sugar beet as affected by interaction between humic acid and boron fertilization during 2017/ 2018 season

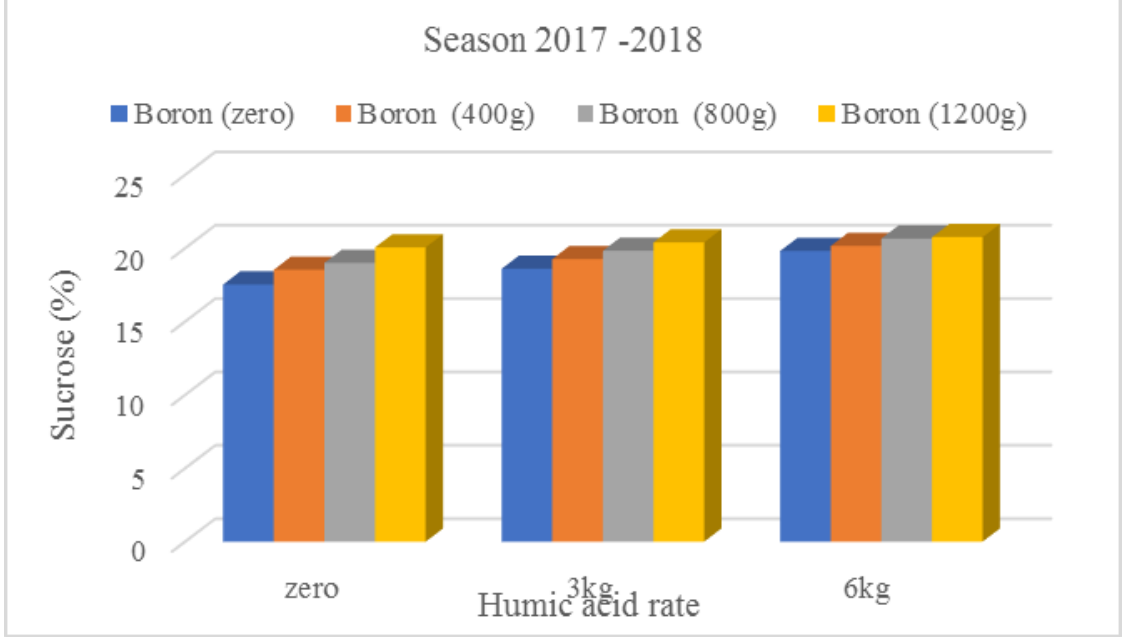

Fig 4.a. Sucrose (\%) of sugar beet as affected by interaction between humic acid and boron fertilization during 2017/2018 season 
application of humic acid and boron (spraying with water) in both seasons

Results in Table (4), demonstrated the effect of humic acid, boron fertilization and their interaction on potassium $\%, \alpha$ - amino nitrogen $\%$, sodium $\%$ and white sugar \% during 2016/2017 and 2017/ 2018 seasons.

Results reported in that table demonstrated that increasing humic acid rates from zero to $3 \mathrm{~kg} / \mathrm{fed}$ and $6 \mathrm{~kg} / \mathrm{fed}$ decreased significantly $\alpha$-amino nitrogen percentage and sodium percentage in sugar beet root, during 2016/2017 and 2017/2018 seasons, where the lowest mean values obtained when adding $6 \mathrm{~kg} / \mathrm{fed}$. Whereas the highest mean values resulted from growing sugar beet plant under the control treatment ( zero humic acid / fed ) This result is to be expected due to the increase of potassium nitrate in the juice when the addition of the humic acid, which would block the crystallization of sugar and increase losses in molasses. Similar results were obtained by Motaghi and Nejad (2014) and Shaban et al. (2014).

Increasing humic acid rates from zero up to $6 \mathrm{~kg} / \mathrm{fed}$ increased significantly potassium percentage and white sugar percentage during 2016/2017 and 2017/2018 seasons as shown in Table (4). Where the highest mean values when adding $6 \mathrm{~kg} /$ fed. Whereas the lowest mean values obtained by growing sugar beet plant under control treatment (zero $\mathrm{kg} / \mathrm{fed}$ humic acid) during the two seasons. While there, was no significant effect between the concentrations of $3 \mathrm{~kg} / \mathrm{fed}$ and $6 \mathrm{~kg} / \mathrm{fed}$ on the mean values of potassium percentage in the first season, as shown in table (4). These results are in harmony with tease obtained by Shoae et al. (2013), ELBassiouny et al. (2014), and Shaban et al. (2014). The study confirmed that humic acid application increased roots yield, sugar yield as shown previously in Table (2), and increased TSS\%, sucrose \%and purity \% as shown in Table (3), as well as decreased the proportion of some salts in the juice such as $\alpha$ - amino nitrogen $\%$ and $\mathrm{Na} \%$. Table (4). Moreover, results presented in Table (4) showed that increasing boron fertilization from zero up to $1200 \mathrm{~g} / \mathrm{fed}$ decreased significantly potassium $\%, \alpha$ - amino nitrogen $\%$, and sodium $\%$ in sugar beet root during 2016/2017 and 2017/2018 seasons. Where the lowest mean values percentage were recorded when applying the rate of $1200 \mathrm{~g} / \mathrm{fed}$ of boron during the two seasons. However, the highest mean values were recorded under control treatment (zero g/fed) during both seasons. These results are in harmony with these obtained by EL-Kamash (2007), Osman (2008) and Ferweez et al. (2011).

In addition, data reported in Table (4) demonstrated that increasing boron fertilization increased significantly white sugar percentage during 2016/2017 and $2017 / 2018$ seasons. Where the highest mean values of white sugar percentage were recorded when applying $1200 \mathrm{~g} /$ fed boron fertilization. While the lowest mean values were under the control treatment zero boron $\mathrm{g} / \mathrm{fed}$ during the two seasons. This result is in harmony with that obtained by EL-Geddawy et al. (2007), EL-Kamash (2007) and Osman (2008)

Table 4. Some quality attributes of sugar beet as affected by humic acid, boron fertilization and their interaction during 2016/17 and 2017/ 2018 seasons

\begin{tabular}{|c|c|c|c|c|c|c|c|c|}
\hline \multirow[t]{2}{*}{ Treatments } & \multicolumn{2}{|c|}{ Potassium \% } & \multicolumn{2}{|c|}{$\alpha$-amino nitrogen $\%$} & \multicolumn{2}{|c|}{ Sodium \% } & \multicolumn{2}{|c|}{ White sugar \% (ZB\%) } \\
\hline & $\begin{array}{c}2016 / 1 \\
7\end{array}$ & $\begin{array}{c}2017 / 1 \\
8\end{array}$ & $\begin{array}{c}2016 / 1 \\
7\end{array}$ & $2017 / 18$ & $2016 / 17$ & $2017 / 18$ & $2016 / 17$ & $2017 / 18$ \\
\hline \multicolumn{9}{|c|}{ H) Humic acid (kg/fed) } \\
\hline $\begin{array}{l}\mathrm{H}_{1}(0) \text { water } \\
\text { spraying }\end{array}$ & $4.42 b$ & $4.75 \mathrm{c}$ & $2.65 \mathrm{a}$ & $2.73 \mathrm{a}$ & $0.80 \mathrm{a}$ & $0.81 \mathrm{a}$ & $16.14 \mathrm{c}$ & $16.31 \mathrm{c}$ \\
\hline $\mathrm{H}_{2} \quad(3)$ & $5.26 \mathrm{a}$ & $5.46 \mathrm{~b}$ & $2.6 \mathrm{a}$ & $2.44 \mathrm{~b}$ & $0.67 b$ & $0.69 b$ & $17.00 \mathrm{~b}$ & $16.94 \mathrm{~b}$ \\
\hline $\mathrm{H}_{3} \quad(6)$ & $5.45 \mathrm{a}$ & $5.68 \mathrm{a}$ & $2.50 \mathrm{~b}$ & $2.52 \mathrm{~b}$ & $0.67 \mathrm{~b}$ & $0.67 \mathrm{c}$ & $17.70 \mathrm{a}$ & $17.70 \mathrm{a}$ \\
\hline $\begin{array}{l}\text { LSD at } 0.05 \\
\text { B) Boron }(\mathrm{g} / \mathrm{f}\end{array}$ & 0.23 & 0.13 & 0.13 & 0.086 & 0.0099 & 0.019 & 0.21 & 0.33 \\
\hline $\begin{array}{l}\mathrm{B}_{1}(0) \text { water } \\
\text { spraying }\end{array}$ & $5.69 \mathrm{a}$ & $5.83 a$ & $2.94 \mathrm{a}$ & $2.88 \mathrm{a}$ & $0.79 \mathrm{a}$ & $0.79 \mathrm{a}$ & $15.90 \mathrm{c}$ & $15.80 \mathrm{~d}$ \\
\hline $\mathrm{B}_{2}(400)$ & $5.12 b$ & $5.36 \mathrm{~b}$ & $2.72 b$ & $2.64 \mathrm{~b}$ & $0.71 \mathrm{~b}$ & $0.73 b$ & $16.94 \mathrm{~b}$ & $16.67 \mathrm{c}$ \\
\hline $\mathrm{B}_{3}(800)$ & $4.85 c$ & $5.27 \mathrm{~b}$ & $2.51 \mathrm{c}$ & $2.50 \mathrm{c}$ & $0.68 \mathrm{c}$ & $0.70 \mathrm{c}$ & $16.96 \mathrm{~b}$ & $17.24 \mathrm{~b}$ \\
\hline $\mathrm{B}_{4}(1200)$ & $4.52 \mathrm{~d}$ & $4.73 \mathrm{c}$ & $2.24 \mathrm{~d}$ & $2.24 \mathrm{~d}$ & $0.68 \mathrm{c}$ & $0.67 \mathrm{~d}$ & $17.97 \mathrm{a}$ & $18.23 \mathrm{a}$ \\
\hline LSD at 0.05 & 0.26 & 0.23 & 0.073 & 0.075 & 0.015 & 0.0084 & 0.24 & 0.36 \\
\hline$\underline{\text { Interaction }}$ & & & & & & & & \\
\hline $\mathrm{H} \times \mathrm{B}$ & NS & 0.68 & 0.22 & 0.23 & 0.041 & 0.025 & 0.73 & NS \\
\hline
\end{tabular}

Means followed by the same letter in the same column are statistically equaled according to L.S.D0.05 values.

NS: not significant difference at 0.05 level of probability 
Moreover, data in that table demonstrated that the interaction between humic acid and boron fertilization affected significantly $\alpha$ - amino nitrogen $\%$ and sodium $\%$ during 2016/2017 and 2017/2018 seasons and potassium\% during the second season, only as well as white sugar\% during the first season. This showed that humic acid and boron fertilization act dependently on $\alpha$ amino nitrogen $\%$, sodium $\%$, potassium $\%$ and white sugar\% under this study

\section{CONCLUSION}

According to this study, it could be concluded that Francisco sugar beet cultivar treated with $6 \mathrm{~kg} /$ fed humic acid and $1200 \mathrm{~g}$ of boron in the form of (Nutribor) to increase productivity parameters of sugar beet and decreased the proportion of some impurities in the juice therefore lack of sugar loss in molasses. As well as increase root and sugar yield ton/fed, sugar extraction percent and sugar quality under the conditions of Nubaria region.

\section{REFERENCES}

Abdel-Motagally, F.M.F. 2015. Effect concentration and spraying time of boron on yield and quality traits of sugar beet grown in newly reclaimed soil conditions. Assiut J. Agric. Sci., 46(6):15-26.

Aly, M.S.E.M. 2005. Study of some factors affecting productivity of sugar beet. Ph.D. Thesis, Fac. Agric., AlAzhar Univ., Egypt.

Armin, M. and M. Asgharipour.2012. Effect of time and concentration of boron foliar application on yield and quality of sugar beet. American-Eurasian J. Agric. and Environ. Sci., 12 (4): 444-448.

Azzazy, N.B. 2006. Yield and quality of some sugar beet varieties as affected by water quality and nitrogen fertilization. Egypt J. Agric. Rec.,82(4):1733-1745.

CoStat, Ver. (6.4). 2005.Cohort software798 light house Ave. PMB320, Monterey, CA93940, and USA. email: info@cohort.com and Website: http://www.cohort.com/DownloadCoStatPart2.html

El- Bassiouny, H.S.M., A. B. Bakry, A. A. Attia and M. M. Abd Allah.2014. Physiological role of humic acid and nicotinamide on improving plant growth, yield, and mineral nutrient of wheat (Triticum durum) grown under newly reclaimed sandy soil, Agric. Sci., 5(8): 687-700.

El-Geddawy, I.H., M. S.E. Osman, M.G.A. Taha and S.A.A.M. Enan.2007. Transplanting using paper pots technique and micro-nutrition with relation to yield and it is attributes of sugar beet at different planting dates. Egypt J. Agri. Res., 85(1):191-210.

El-Geddawy, I.H., A.A. El-Hosary, A. M. M. Saad and B. S. Ibrahim. 2007. Effect of boron and molybdenum on growth and yield of some sugar beet varieties. Egypt J. Agric. Res., 85(4):1355-1366.
El-Hassanin, A.S., S.M.R Moustafa, N. Shafika, A.M. Khalifa and M. Ibrahim. 2016. Effect of foliar application with humic acid substances under nitrogen fertilization levels on quality and yields of sugar beet plant. J. Curr. Microbiol. App. Sci 5(11):668-680.

El-Kamash, T.N.M. 2007. Effect of nitrogen and boron fertilization on yield and quality of sugar beet in kalabsha area, dakahlia governorate. M.Sc. Thesis, Sugar Technology Res., Assuit Univ., Egypt.

El-Sherief, M. A., B. Sahar, M. I. Moustafa and M. M. S. Neana.2016. Response of sugar beet yield and quality to some micronutrients under sandy soil. J. Soil Sci. and Agric. Eng., Mansoura Univ., 7 (2): 97-106.

Ferweez, H., M.F.M. Ibrahim and A.M. Allan.2011. Improving yield and quality of sugar beet using boron at different levels of nitrogen fertilizer. Alex Sci. Exch. J.,32(56):1-8.

Gomaa, M.A., F.I. Radwan, G.A.M. Khalil, E.E. Kandil and M.M. El-Saber.2014. Impact of humic acid application on productivity of some maize hybrids under water stress conditions. Middle East J. Appl. Sci., 4(3):668-673.

Kabu, M. and M.S. Akosman.2013. Biological effects of boron. Rev. Environ. Contam. Toxicol., 225:57-75.

Kristek, S., I. Resic, J. Jovic, K. Zmajic, L. Lenart, Z. Kraljicak, D. Beslo and S. Rasic. 2018. Effect of various rates of boron on yield and quality of high-grade sugar beet varieties. Listy Cukrovarnicke a Reparske, 134(4): 146-150

Mekdad, A.A.A.2015. Sugar beet productivity as affected by nitrogen fertilizer and foliar spraying with boron. Int.J.Curr.Microbiol.App.Sci 4(4):181-196.

Motaghi, S. and M. Nejad.2014. The effect of different levels of humic acid and potassium fertilizer on physiological indices of growth. Inter. J. Biosci., 5(2):99-105.

Nemeat -Alla, E. A. E and I.H.M. El-Geddawy.2002. Response of sugar beet to foliar spraying time with micronutrients under different level nitrogen and phosphorus fertilization. J. Agric. Res. Tanta Univ. Vol. 27(4), 670-691.pp

Osman, M. F. O. 2008. response of sugar beet to phosphorus, potassium and microelements fertilization.M.Sc. Thesis Fac. of Agric. (Saba Basha), Alex. Egypt.

Piper, C. S. 1950. Soil and plant analysis. Univ. of Adelaide, Australia.

Rassam, G., A. Dadkhah, Y. A. Khoshnood and M. Dashti.2015. Impact of humic acid on yield and quality of sugar beet (Beta vulgaris L.) grown on calcareous soil. Not. Sci. Biol., 7(3):367-371.

Saif, L.M.A. 1991. Step wise regression and path coefficient analysis for some sugar beet characters under levels of boron and nitrogen fertilization. Proc. $9^{\text {th }}$ Conf. Agronomy. Minufiya Univ.,569-581. 
Shaban, K.H.A. H., E. M. Abdel Fatah and D. A. Syed.2014. Impact of humic acid and mineral nitrogen fertilization on soil chemical properties and yield and quality of sugar beet under saline soil.J . Soil. Sci. and Agric. Eng., Mansoura Univ. Vol. 5 (10):1335 - 1353.

Shoae, S.M., F. Paknejad and H.H. Darvishi .2013. Effect of intermittent furrow irrigation, humic acid and deficit irrigation on shoae water use efficiency of sugar beet. Annals of Biolog. Res.,4 (2):187-193.
Steel, R.G.D. and J.H. Torrie.1981. Principles of Statistics a Biometrical Approach. $2^{\text {nd }}$ ed. McGraw-Hills International Book Company, Singapore, 633p.

Sugar Crops Council. 2017. Sugar crops production in Egypt, agricultural production season of 2015/ 2016, extraction season of 2016. Annual report of May 2017: (81- 83). Cairo, Egypt. 155 pp. 


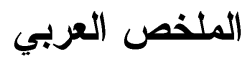

\section{أنتاجية وجودة بنجر السكر وعلاقتهما بحامض الهيوميك والتسميد بالبورون تحت ظروف النوبارية}

ابر اهيم فتح الله رحاب ، سامية سعد السيد المغربى ، عصام اسماعيل اسماعيل قنديل و ناهد يوسف ابر اهيم يوسف

الهيوميك أدت الى انخفاض نسبة شوائب الصوديوم و الفا

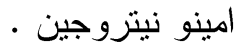

كما أدت الزيادة في مستويات الرش الورقي لعنصر البورون لزيادة معنوية في صفات المحصول ومكوناته وصفات الجودة بنجر السكرحيث أنه بزيادة تسميد البورون

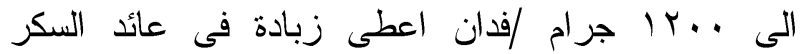
ومحصول الجذور والسكر الابيض ( طن /للفدان ) ونسبة النقاوة وفي حين حدث انخفاضًاً ملحوظاً فى نسبة الصوديوم و الفا أمينو نيتروجين و البوتاسيوم. كما أثز التفاعل بين حمض الهيوميك و التسميد بالبورون معنوياً على صفات المدروسة حيث زاد المحصول البيولوجى ومحصول السكر (طن /للفدان) زيادة معنوية وفي حين حدث انخفاض فى نسبة الثوائب فى العصير (الصويوم - الفا أمينو نيتروجين - البوتاسيوم) وايضا زادي النسبة المئوية للسكرونسبة المواد الصلبة الكلية والجودة فى الموسمين ونسبة الاستخلاص فى الموسم الثانى لبنجر السكر تحت ظروف هذه الدراسة. وتوصي الدراسة بزر اعة بنجر السكر و التسميد بحامض

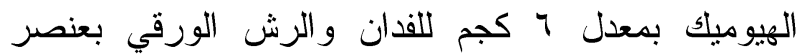
البورون بمعدل . . Y جم للفدان حيث أن هذه التوليفة ادت لزيادة في صفات المحصول وجودته تحت ظروف منطقة النوبارية.
أقيمت تجربتان حقليتان فى الكيلو ^ـ طريق الاسكندرية القاهرة الصحر اوى - منطقة النوبارية - البحيرة - مصر

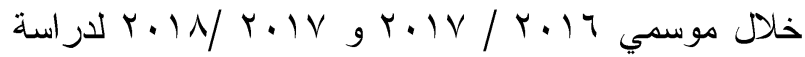
تاثير حامض الهيوميك و التسميد بالبورون على أنتاجية وجودة محصول بنجر السكر يث استخدم حمض الهيومك فى ثلاثة مستويات ( الرش بالماء (كنترول) ، س، اكجم /فدان) و البورن فى اربعة مستويات (الرش بالماء (كنترول)

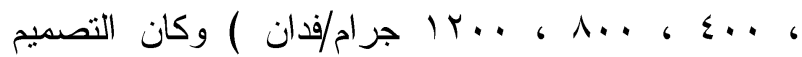
المستخدم القطع المنشقة مرة واحدة فى ثلاث مكررات وتم توزيع مستويات حامض الهيوميك فى القطع الرائسية وومعدلات الرش الورقي للبورون فى القطع الفرعية ) المنشقة ). وكان ميعاد الزراعة في ب ، 0 اكتوبر خلال موسمي

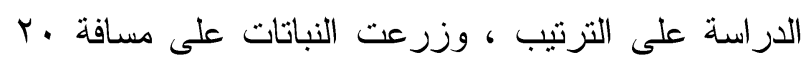
سم بين الجور وبين الخطوط ·. سم ، وكانت مساحة

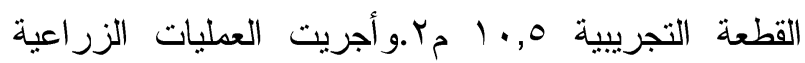
الأخري على حسب توصيات وزارة الزر اعة للمنطقة. ولخصت أهم النتائج المتحصل عليها في التالى : أثرت الزيادة في معدلات حامض الهيوميك معنوياً على صفات المحصول ومكوناته والجودة في بنجر السكر حيث ادى استخدام حمض الهيوميك 7 كجم للفدان الى زيادة معنوية فى كل من محصول الجذور ومحصول الاوراق و المحصول البيولوجى ومحصول السكر ومحصول السكر الابيض (طن /للفدان ) و النسبة المئوية للمواد الصلبة الكلية ونسبة السكروز في حين أن الزيادة في معدلات حامض 